$$
\begin{aligned}
& \text { 薬 物 } \\
& \text { 突発性難聴における塩酸ビフェメランの治療 } \\
& \text { 一実験データを基にしてー } \\
& \text { 柳田 則之 } \left.{ }^{1)} \cdot \text { 中島 務 } 1\right) \cdot \text { 杀崎 博伸 }{ }^{1)} \\
& \text { 中井 義明2) - 小西 一夫2) - 杵谷 治彦2) } \\
& \text { 佐藤 喜一3) }
\end{aligned}
$$

\title{
Bifemelane Hydrochloride Therapy for Sudden Deafness
}

\author{
Noriyuki Yanagita, Tsutomu Nakashima and Hironobu Morisaki \\ (Nagoya University) \\ Yoshiaki Nakai, Kazuo Konishi and Haruhiko Masutani \\ (Osaka City University) \\ Kiichi Sato \\ (Japanese Embassy to Thailand)
}

\begin{abstract}
Various therapeutic regimens have been used in the treatment of sudden deafness, one of the sensori-neural hearing losses in which recovery is generally considered to be possible in the early stage of the disease. Drugs which improve the blood flow of the inner ear, cerebral metabolism activators and anti-neuritis agents are widely used. We used bifemelane hydrochloride, a cerebral function improver, to treat 80 patients suffering from sudden deafness. The drug was found to be as effective as other medications. Since combination therapies are popular for the treatment of sudden deafness, bifemelane may be a positive drug in combination therapy.

Animal experiments were also performed to clarify the mechanism of action of bifemelane. The results indicate that bifemelane dilates cochlear blood vessels and increases blood flow.
\end{abstract}

Key words: sudden deafness, bifemelane hydrochloride, cochlear blood flow and vessels, hearing recovery

1）名古屋大学医学部耳鼻咽喉科学教室

2) 大阪市立大学医学部耳鼻咽喉科学教室

3）タイ国日本大使館参事（元：公立羽咋病院耳鼻咽喉科） 
はじめに

突発性難聴は，その初期に打いては聴力回復 が期待できる数少ない感音難聴であることから， その病態や治療について数多く報告されてき た1) 3).

実際の治療に当っては, 図 1 亿示す如くその 原因・病態を考慮して行らべきことは当然であ

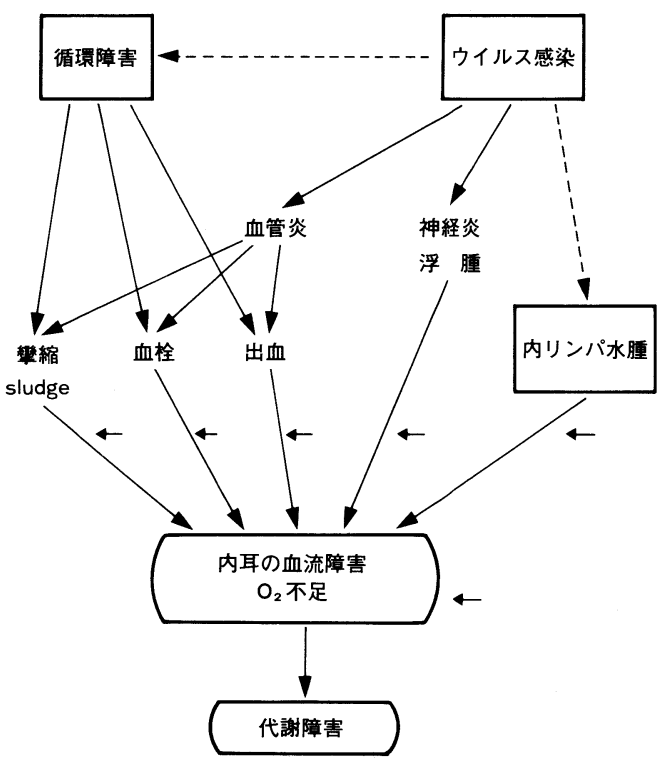

$\leftarrow$ 治療薬の目的

図 1 突発性難聴の原因・病態と治療

表 1 治療法

1）血管拡張剂，ATP，ビタミンB

2) SGB

3) ステロイドホルモン

4) ウロキナーゼ

5 ）低分子デキストラン

6 ）ウログラフィン

7 ）極超短波

8 ）高気圧酸素

9) L-V 療法

10）カルシウム拮抗剤

11) Batroxobin (DF)

12) $\mathrm{PGE}_{1}$
るが，肝心のこの点に関しては，尚不明な点が 多い.

現在行われている主な治療法を年代順に表 1 に示した．これらは殆どが併用療法で行われて いる.これら治療の方法について種々の意見が あるが，その中でも内耳循環の改善, 脳・内耳 代謝の賦活, 抗神経炎の治療薬は広く使用され ている.

今回, 脳血管性精神症状改善剂(脳神経伝達 改善作用, 脳エネルギー代謝賦活作用を有する） である塩酸ビフェメラン(商品名アルナート $\left.{ }^{\circledR}\right)$ を突発性難聴に使用する機会を得たので，著者 らが行ってきた基礎的実験データと併せて，そ の有効性, 安全性执よび有用性についてその成 績を報告する。

\section{基礎的実験成績}

著者のらち中井・枡谷らは Wister 系ラット 15匹を用いて塩酸ビフェメラン $10 \mathrm{mg} / \mathrm{kg}$ ある いは $20 \mathrm{mg} / \mathrm{kg}$ を頸静脈より投与し， 3 分後に 左心室より $5 \%$ ホルマリンにて灌流固定, 内耳 血管鋳型を作成し, SEM にて蝸牛各部の血管 を写真撮影し，血管内径(直径)を測定した。 そ の成績は表 2 亿示す如くであり, ラセン勒帯動 静脈吻合に执いて塩酸ビフェメラン $10 \mathrm{mg} / \mathrm{kg}$, $20 \mathrm{mg} / \mathrm{kg}$ 静注群の両群とも各回転においてコ ントロール群と比較して血管径に有意の拡張を 認めた. 図 2 は静注後の血管径の拡張を示すも のである.この拡張作用により蝸牛血流が増加 することを結論づけた. 尚, 固有蝸牛動脈, 放 射状細静脈，血管条毛細管，集合静脈，後ラセ ン静脈の各血管径に拈いてはコントロール群と 比較して有意の差を認めなかった。

森崎らはモルモット22匹を用いてレーザード ップラー法により塩酸ビフェメラン静注による 蝸牛血流, 脳血流の影響を全身血圧を測定しな がら観察した。

図 3 の如く実験 1 として, はじめに生食, 次 に塩酸ビフェメランを $1.25 \mathrm{mg} / \mathrm{kg}, 2.5 \mathrm{mg} / \mathrm{kg}$, $5 \mathrm{mg} / \mathrm{kg}, 10 \mathrm{mg} / \mathrm{kg}$ と濃度の低い順に約 20 分 間の間隔をあけて 1 分間で体重 $1 \mathrm{~kg}$ 当り $1 \mathrm{ml}$ 


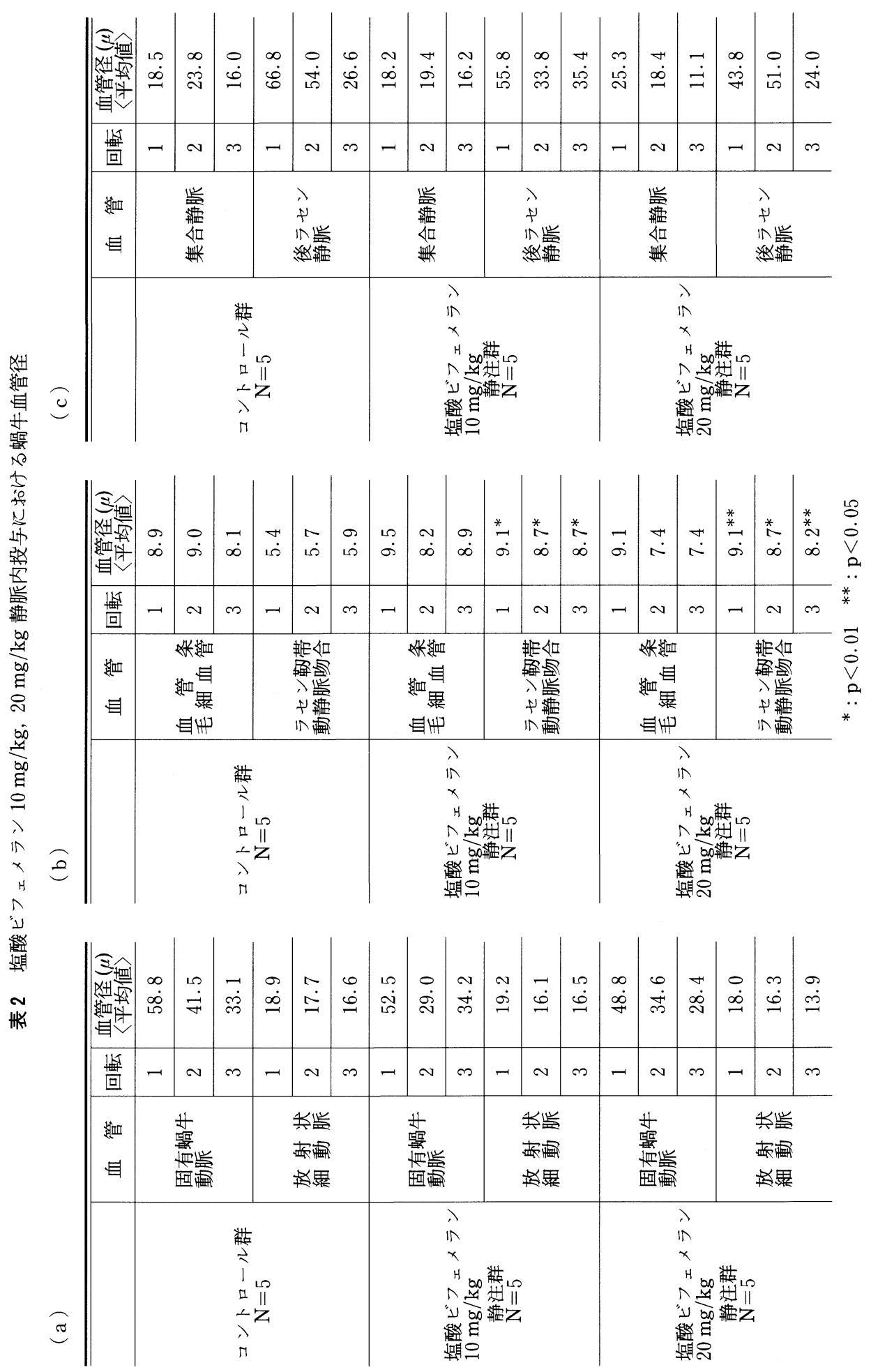


を投与した。実験 2 として無呼吸を2 分間かけ たのち約 20 分後に生食, 次に塩酸ビフェメラン $0.25 \mathrm{mg} / \mathrm{kg}, 0.5 \mathrm{mg} / \mathrm{kg}, 1.25 \mathrm{mg} / \mathrm{kg}, 2.5 \mathrm{mg} /$ $\mathrm{kg}$ を濃度の低い順に同様に静注し, その20分 後に無呼吸を 2 分間施行した. 図 4 に示す如く 塩酸ビフェメラン静注後, 蝸牛血流, 脳血流, 血圧は増加した。 いずれの濃度でも蝸牛血流特 よび脳血流のピークは血圧より早くなっていた。 無呼吸の負荷では, 四 5 に示す様に塩酸ビフェ メラン投与前と投与後を比較すると, 塩酸ビフ ェメラン投与後の無呼吸負荷では蝸牛血流, 脳

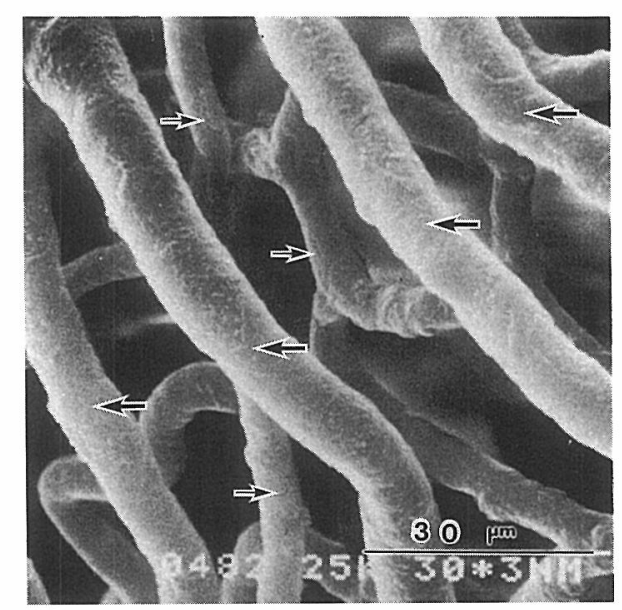

図 2 塩酸ビフェメラン投与後の外側蝸牛壁 の血管 ラセン靯帯血管の拡張がみられる。 大さい矢印：ラセン勒帯の血管 小さい矢印：血管条の血管
血流，血圧は高く維持される傾向を示した。 た，奴久妻，佐藤ら5) は酸素欠乏モルモットに 捈いて ABR を測定し，塩酸ビフェメランが有 効であることを報告している.

以上 3 施設に括ける実験成績から塩酸ビフェ メラン静注により蝸牛血流は増加を示すことが 明らかとなった。

\section{臨床成績}

対象は1990年 1 月より1992年 2 月までの $26 カ$ 月間に名古屋大学耳鼻咽喉科拈よび大阪市立大 学耳鼻咽喉科を受診し，塩酸ビフェメランを投 与した突発性難聴患者 80 例 (名古屋大学34例, 大阪市立大学 46 例)である。

投与方法としては，塩酸ビフェメラン(アル ナート $\left.{ }^{\circledR}\right) 1$ 錠50 mgを 1 日 3 回経口投与した.

患者の性別, 年齢構成, 発症から治療までの 期間, 初診時の平均聴力レベル $(250,500,1000$, $2000,4000 \mathrm{~Hz} 5$ 周波数の平均), めぬいの有無, 患側拉よび投与期間は表 3 に示した如くである. 投与期間は患者の聴力回復の状態にもよるが, 1 週間未满は 1 例のみで, 他の全ての症例は 1 週間以上投与した。年齢構成は他の報告3)之あ まり差はみられなかった。

全患者の詳細は表 4 に示した。全症例に拈い て他剤との併用療法が施行された。尚, 聴力回 復の判定は厚生省班研究の判定基準 (1984年改 正に基ついて行った.

先ず, 治療前(初診時) と最終検査時の聴力の 回復の状態すなわら聴力改善度を発症からの期

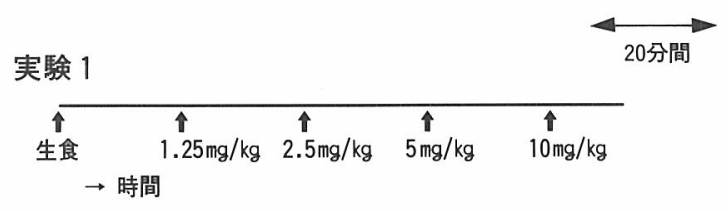

実験 2

\begin{tabular}{|c|c|c|c|c|c|c|}
\hline $\begin{array}{c}\hat{\uparrow} \\
\text { 無呼吸 } \\
\text { (2 分間) }\end{array}$ & $\begin{array}{c}\text { 令 } \\
\text { 生食 }\end{array}$ & $\begin{array}{c}\hat{\uparrow} \\
0.25 \mathrm{mg} / \mathrm{kg}\end{array}$ & $\stackrel{\uparrow}{\uparrow}=.5 \mathrm{mg} / \mathrm{kg}$ & $\stackrel{\uparrow}{1.25 \mathrm{mg} / \mathrm{kg}}$ & $\stackrel{\uparrow}{2.5 \mathrm{mg} / \mathrm{kg}}$ & $\begin{array}{c}\hat{\imath} \\
\text { 無呼吸 } \\
\text { (2 分間) }\end{array}$ \\
\hline
\end{tabular}

図 3 レーザードップラー法による蝸牛血流測定 塩酸ビフェメラン投与のプロトコール(実験 1 と実験 2 ). 
(a)

塩酸ビフェメラン $0.5 \mathrm{mg} / \mathrm{kg}$
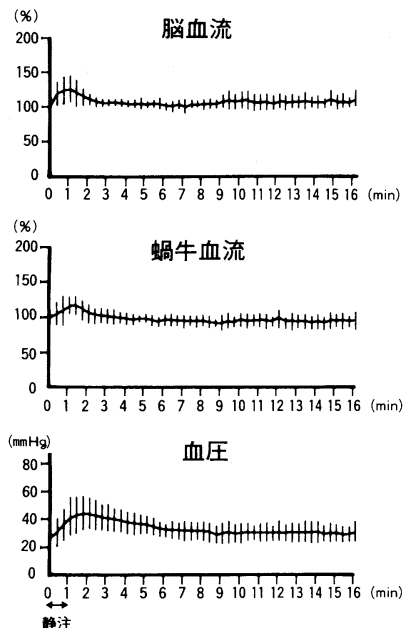

(b)
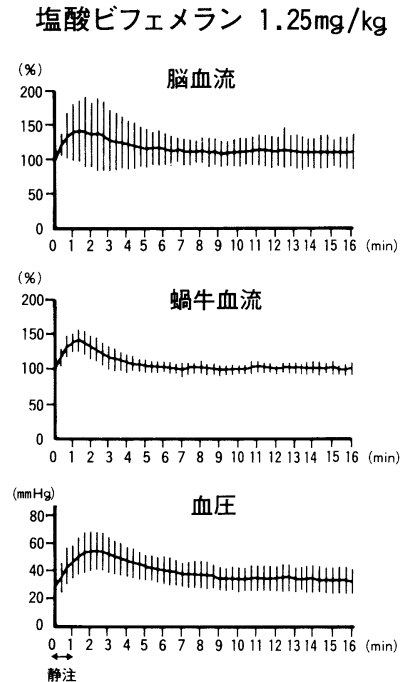

(c)

塩酸ビフェメラン $5 \mathrm{mg} / \mathrm{kg}$
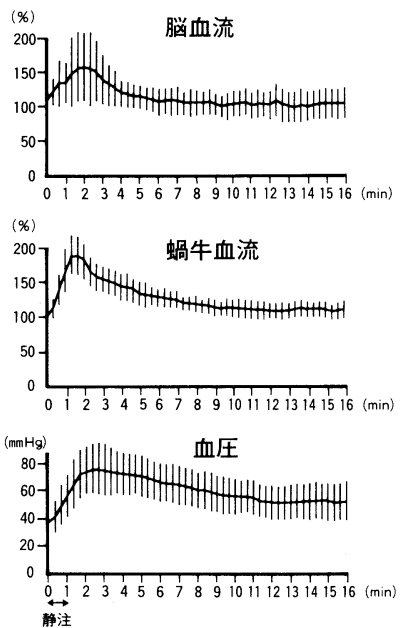

図 4 塩酸ビフェメラン $0.5 \mathrm{mg} / \mathrm{kg}, 1.25 \mathrm{mg} / \mathrm{kg}, 5 \mathrm{mg} / \mathrm{kg}$ 静注後の脳血流, 蝸牛血流, 血圧 への影響
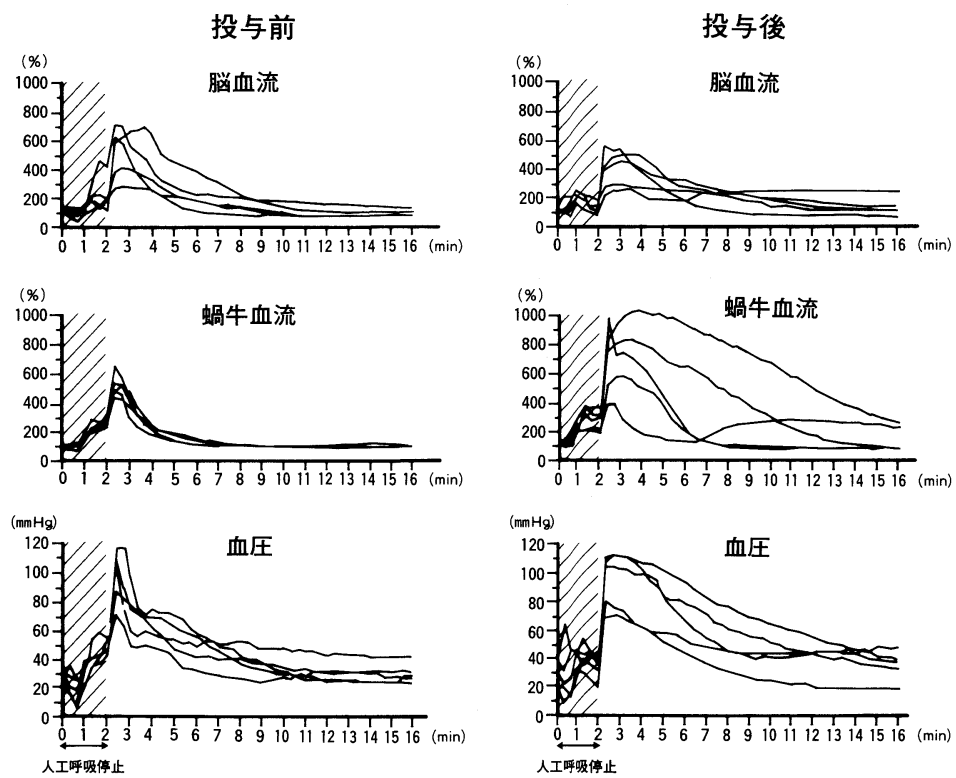

図 5 塩酸ビフェメラン投与前後の無呼吸負荷 ( 2 分間)時の脳血流, 蝸牛血流, 血圧への影響 
間別にみたのが表 5 である. 初診時平均聴力 ( 5 周波数の平均) が $30 \mathrm{~dB}$ 以内のごく軽度の ものは除外して $1 \sim 4$ 病日, $5 \sim 7$ 病日, $8 \sim$ 14病日, $15 \sim 30$ 病日, 31病日以上に区分して検 討したが，早期のもの程聴力回復は良好である. これを更に各病日期に扣ける聴力回復の推移を 平均聴力レベルについてグラフで示すと図 6 の ようになる。

すなわち，1〜4病日に投与したものについ

表 3 背景因子

\begin{tabular}{|c|c|c|c|c|}
\hline & & 症例数 & 名古屋大 & 大阪市大 \\
\hline \multirow[t]{2}{*}{ 性＼cjkstart別 } & 男 & 38 & 16 & 22 \\
\hline & 女 & 42 & 18 & 24 \\
\hline \multirow{4}{*}{$\begin{array}{l}\text { 年 佱) } \\
\text { 龄 }\end{array}$} & $\sim 10$ & 0 & 0 & 0 \\
\hline & $11 \sim 39$ & 23 & 8 & 15 \\
\hline & $40 \sim 59$ & 42 & 20 & 22 \\
\hline & $60 \sim$ & 15 & 6 & 9 \\
\hline \multirow{5}{*}{$\begin{array}{c}\text { 発症から } \\
\text { 治療まで } \\
\text { の期間 } \\
\text { (日) }\end{array}$} & $0 \sim 4$ & 39 & 18 & 21 \\
\hline & $5 \sim 7$ & 16 & 6 & 10 \\
\hline & $8 \sim 14$ & 11 & 4 & 7 \\
\hline & $15 \sim 30$ & 9 & 3 & 6 \\
\hline & $31 \sim$ & 5 & 3 & 2 \\
\hline \multirow{4}{*}{$\begin{array}{l}\text { 平均聴力 } \\
\text { レヘ }\end{array}$} & $\sim 59$ & 39 & 15 & 24 \\
\hline & $60 \sim 79$ & 18 & 8 & 10 \\
\hline & $80 \sim 90$ & 9 & 4 & 5 \\
\hline & $91 \sim$ & 14 & 7 & 7 \\
\hline \multirow[t]{4}{*}{ めまい } & 無 & 65 & 30 & 35 \\
\hline & 回転性 & 5 & 1 & 4 \\
\hline & 非回転性 & 9 & 2 & 7 \\
\hline & 不 明 & 1 & 1 & 0 \\
\hline \multirow[t]{3}{*}{ 患 側 } & 右 & 27 & 13 & 14 \\
\hline & 左 & 50 & 20 & 30 \\
\hline & 左·右 & 3 & 1 & 2 \\
\hline \multirow[t]{7}{*}{ 投与期間 } & 1 週間未満 & 0 & 0 & 0 \\
\hline & 1 週間以上 & 15 & 12 & 3 \\
\hline & 2 週間以上 & 24 & 6 & 18 \\
\hline & 3 週間以上 & 6 & 1 & 5 \\
\hline & 4 週間以上 & 17 & 8 & 9 \\
\hline & 5 週間以上 & 2 & 1 & 1 \\
\hline & 6 週間以上 & 16 & 6 & 10 \\
\hline
\end{tabular}

ては図 6 (a)の如くで, 聴力回復を認めたもの では, その大部分が投与後 2 週間で著明な回復 を認めている。しかし，聴力低下の高度なもの では投与後 $3 \sim 4$ 週間まで回復する症例もみら れた。 しかし， 3 週間を過ぎると回復がみられ るものは少なくなった。 また 2 症例では副作用 のため 1 週間で投与を中止した.

$5 \sim 7$ 病日に投与したものでは図 6 (b)の如 くである.この時期に投与したものでは多くの 症例に聴力の回復が認められるが，その期間は $1 \sim 4$ 病日のものと同様，投与後 2 週間が大部 分を占めている.

$8 \sim 14$ 病日に投与したものでも図 6 (c)の如 く聴力回復はみられるが，そのスピードは 1 ～ $4,5 \sim 7$ 病日のものに比べて悪くなる. 更に 15〜30病日に投与したものでは図 6 (d)の如く 聴力回復は極めて悪くなり，31病日以後になる と図 $6(\mathrm{e})$ の如く，もはや聴力回復は望めない。 次に，14病日以内(15病日以後の経過したもの を除く)のものについて, 初診時平均聴力が 30 $\mathrm{dB}$ 以内のごく軽度のものを除いて, 初診時聴 カレベルと聴力回復との関連をみた，その成績 は表 6 に示す如くである.これをみると 31〜 59 $\mathrm{dB}$ と60〜79 dB のものではむしろ 60〜 $79 \mathrm{~dB}$ の方が聴力回復が良いといら成績が得られたが， $80 \mathrm{~dB}$ 以上の難聴が高度のものになると治癒す るものは極めて少なくなる.

次に14病日以内のものについて年㱓と聴力回 復との関連をみた. 表 7 に示す如く 60 歳以上の 症例には治癒症例が認められず，予後は有意差 をもって悪くなるが，39歳以下と40～59歳では それ程の差はみられない。

耳鳴の改善について，耳鳴の記載のあるもの 53例について関連をみた。耳鳴の予後を著明改 善, 中等度改善, 軽度改善, 不変の 4 段階に区 分して検討した．表 8 に示す如く著明改善が13 例 $(24.5 \%)$ 認められるが，一方不変も 10 例 (18.9\%) みられた. 耳鳴の改善は聴力の回復と 併行することが多く, 聴力回復を第一に考慮す ることが重要である。 


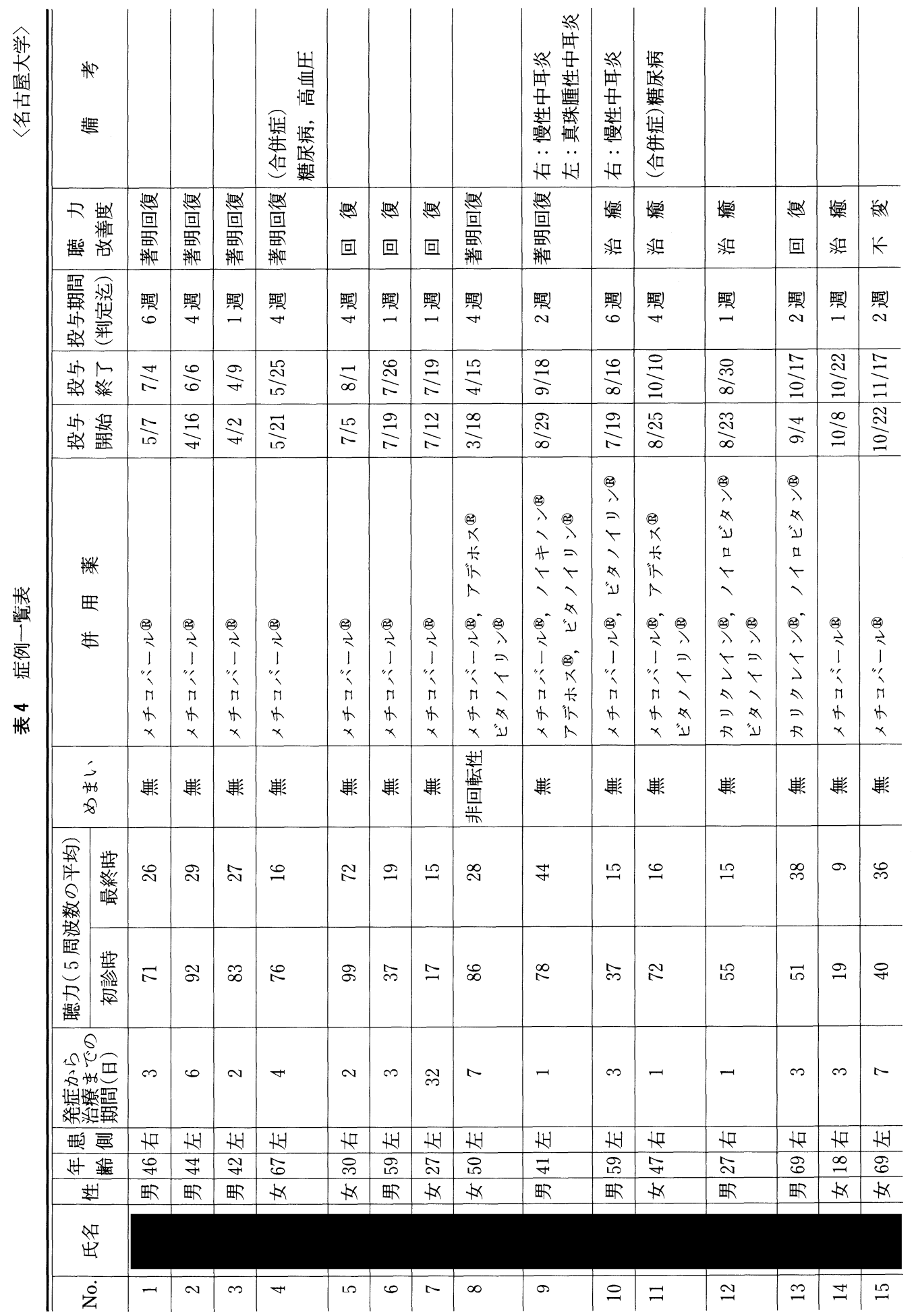




\begin{tabular}{|c|c|c|c|c|c|c|c|c|c|c|c|c|}
\hline 热 & & 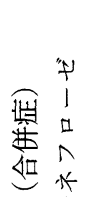 & & & & & & & & & & \\
\hline 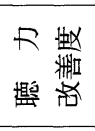 & $\begin{array}{l}\text { 能 } \\
k\end{array}$ & $\begin{array}{l}\text { 紧 } \\
\text { 哲 }\end{array}$ & 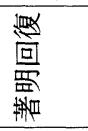 & $\begin{array}{l}\text { 题 } \\
\text { K }\end{array}$ & 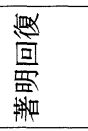 & $\begin{array}{l}\text { 热 } \\
\text { 热 }\end{array}$ & 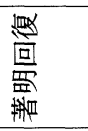 & $\begin{array}{l}\text { 拨 } \\
k\end{array}$ & $\begin{array}{l}\text { 战 } \\
k\end{array}$ & 战 & $\begin{array}{l}\text { 战 } \\
k\end{array}$ & $\begin{array}{l}\text { 的 } \\
k\end{array}$ \\
\hline 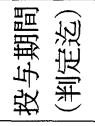 & 巽 & 凛 & $\frac{\pi}{R}$ & $\begin{array}{l}\text { 醴 } \\
\underset{+}{*}\end{array}$ & 碃 & $\begin{array}{l}\text { 嫼 } \\
\stackrel{N}{N}\end{array}$ & $\begin{array}{l}\text { 嘼 } \\
\sim\end{array}$ & 碃 & 些 & 恝 & 然 & $\begin{array}{l}\text { 略) } \\
\stackrel{N}{N}\end{array}$ \\
\hline $\begin{array}{l}1 \\
\text { 留 }\end{array}$ & $\underset{\mathrm{N}}{\mathrm{N}}$ & $\stackrel{\stackrel{10}{N}}{=}$ & $\triangleq$ & $\frac{\widehat{N}}{\mathrm{~N}}$ & $\underset{\mathrm{N}}{\stackrel{N}{ }}$ & $\frac{O}{\beth}$ & $\frac{1}{\sigma}$ & 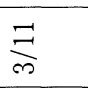 & $\frac{\stackrel{\infty}{o}}{a}$ & 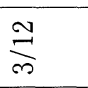 & $\stackrel{\vec{N}}{\Xi}$ & $\stackrel{\Xi}{\exists}$ \\
\hline 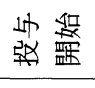 & $\underset{\Delta}{\Delta}$ & $\stackrel{9}{=}$ & $\frac{10}{2}$ & $\vec{m}$ & $\frac{H}{\Delta}$ & $\stackrel{\Xi}{\Xi}$ & $\frac{\curvearrowright}{\infty}$ & $\stackrel{\stackrel{\leftrightarrow}{N}}{\sim}$ & $\bar{\sigma}$ & $\frac{\pi}{m}$ & $\stackrel{\infty}{0}$ & $\stackrel{10}{\exists}$ \\
\hline $\begin{array}{l}\text { 搠 } \\
\text { 国 } \\
\text { 进 }\end{array}$ & 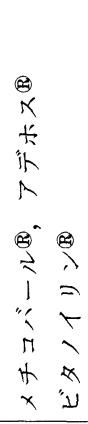 & 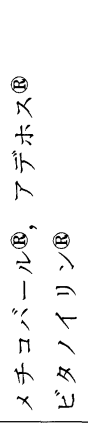 & 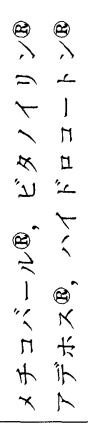 & 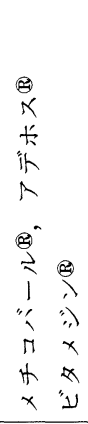 & 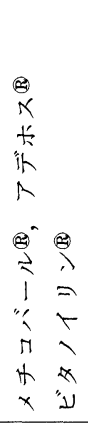 & 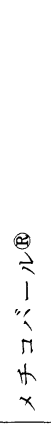 & 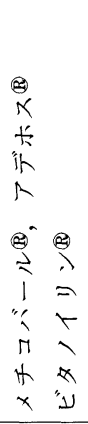 & 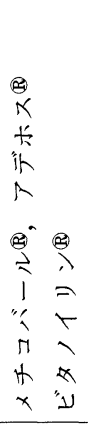 & 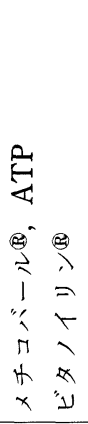 & 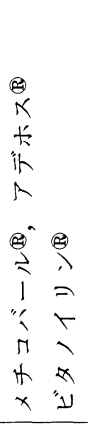 & 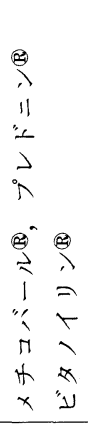 & 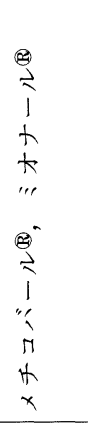 \\
\hline$\underset{1}{3}$ & 岶 & 䒠 & 祡 & 船 & 耤 & 踔 & 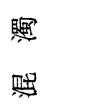 & 热 & 厥 & 耘 & $\begin{array}{l}\Omega \\
\mathbb{m}\end{array}$ & 算 \\
\hline 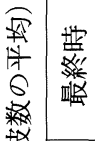 & 点 & 으 & $R$ & $\bar{\sigma}$ & 㝏 & $\Xi$ & 우 & $\overleftarrow{\infty}$ & $\mathscr{q}$ & $\ddot{6}$ & ட & S \\
\hline 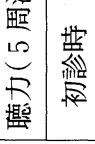 & 우 & 8 & 8 & $\stackrel{\infty}{\circ}$ & Ф્ & $\mathscr{F}$ & $\mathscr{\infty}$ & 8 & i⿱ & $\hat{6}$ & is & $\vec{m}$ \\
\hline 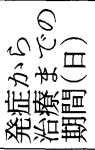 & $N$ & $\neg$ & - & 10 & $\infty$ & $\infty$ & $\infty$ & $\Xi$ & ిㅗ & $\stackrel{\sharp}{N}$ & ల్ల & ஜి \\
\hline 刪 呾 & +4 & +7 & +7 & $\mathrm{HH}$ & HH & HH & सI & HH & +1 & HH & HH & HH K \\
\hline स4 & in & $\mathscr{y}$ & శ్లి & F & $\mathscr{F}$ & i & $\stackrel{2}{2}$ & ले & 8 & F & 8 & है \\
\hline$\$$ & 略 & $\not x$ & $\$ x$ & 略 & $K$ & $A x$ & $\$ x$ & $\$ x$ & 畍 & 䀦 & 㧽 & $A x$ \\
\hline 出 & & & & & & & & & & & & \\
\hline$\dot{\mathrm{z}}$ & 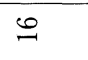 & $\simeq$ & $\stackrel{\infty}{\sim}$ & $\stackrel{9}{\circ}$ & $\stackrel{\sim}{ }$ & $\vec{N}$ & $\widetilde{N}$ & $\dddot{\sim}$ & 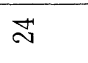 & $\stackrel{\llcorner}{\sim}$ & $\mathscr{N}$ & $\hat{\sim}$ \\
\hline
\end{tabular}




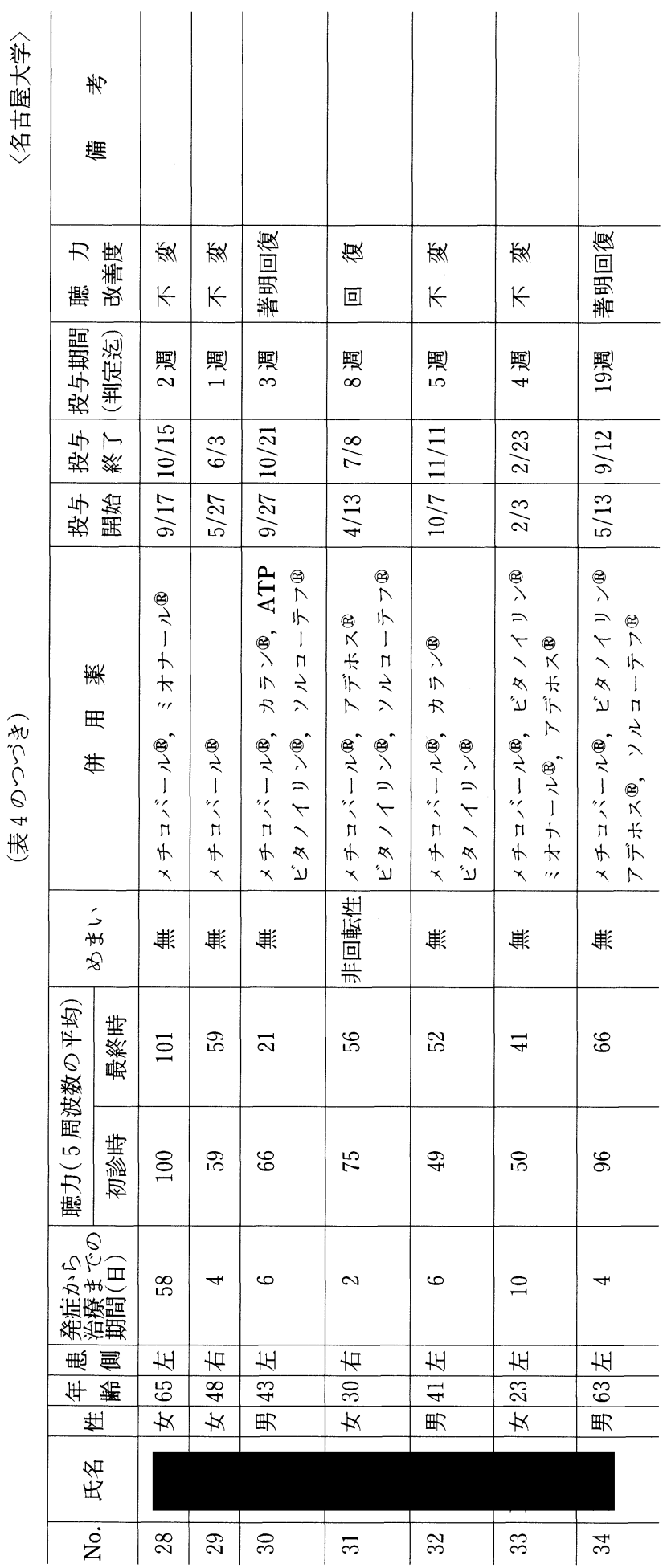

\begin{tabular}{|c|c|c|}
\hline $\begin{array}{l}\text { 把 } \\
\text { 把 }\end{array}$ & & 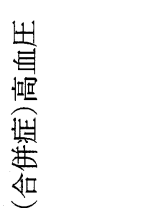 \\
\hline 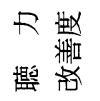 & $\begin{array}{l}\text { 紧 } \\
\text { 哲 }\end{array}$ & $\begin{array}{l}\text { 回 } \\
\text { 这 }\end{array}$ \\
\hline 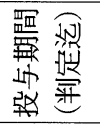 & $\begin{array}{l}\text { 䪲 } \\
\forall\end{array}$ & $\begin{array}{l}\text { 副 } \\
\forall\end{array}$ \\
\hline 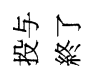 & $\stackrel{\underset{J}{J}}{=}$ & $\stackrel{\oplus}{\approx}$ \\
\hline 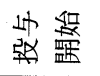 & $\stackrel{ }{ٍ}$ & $\frac{\vec{N}}{b}$ \\
\hline $\begin{array}{l}\text { 煫张 } \\
\text { 压 } \\
\text { 进 }\end{array}$ & 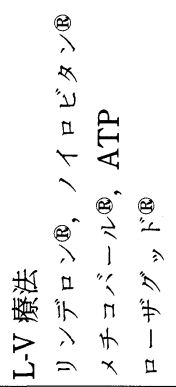 & 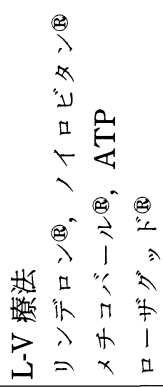 \\
\hline $\begin{array}{c}3 \\
\infty\end{array}$ & 颗 & 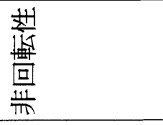 \\
\hline 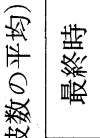 & $\approx$ & $\stackrel{\stackrel{\leftrightarrow}{N}}{ }$ \\
\hline 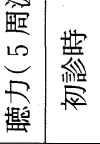 & $\stackrel{10}{\infty}$ & $\mathscr{\forall}$ \\
\hline 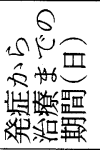 & $\sim$ & 10 \\
\hline 䑶 焉 & $\mathrm{HH}$ & HH \\
\hline सम & กิ & $\overrightarrow{0}$ \\
\hline$\#$ & $\$ x$ & 略 \\
\hline 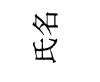 & & \\
\hline$\dot{0}$ & - & $\sim$ \\
\hline
\end{tabular}




\begin{tabular}{|c|c|c|c|c|c|c|c|c|c|c|}
\hline 热 & 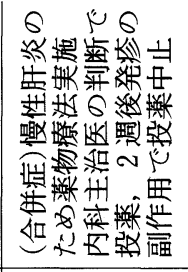 & 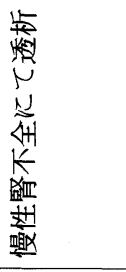 & & & & & 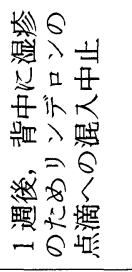 & & & \\
\hline 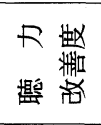 & $\begin{array}{l}\text { 能 } \\
k\end{array}$ & $\begin{array}{l}\text { 繾 } \\
\text { 和 }\end{array}$ & $\begin{array}{l}\text { 回 } \\
\text { 回 }\end{array}$ & 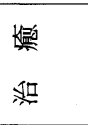 & 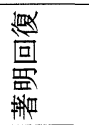 & $\begin{array}{l}\text { 回 } \\
\text { 国 }\end{array}$ & $\begin{array}{l}\text { 解 } \\
k\end{array}$ & $\begin{array}{l}\text { 题 } \\
\text { K }\end{array}$ & $\begin{array}{l}\text { 拨 } \\
k\end{array}$ & $\begin{array}{l}\text { 的 } \\
k\end{array}$ \\
\hline 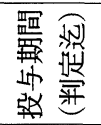 & $\begin{array}{l}\text { 䱈 } \\
\sim\end{array}$ & $\begin{array}{l}\text { 彭 } \\
\text { N }\end{array}$ & $\begin{array}{l}\text { 蛪 } \\
\text { N }\end{array}$ & 毗 & $\begin{array}{l}\text { 糟 } \\
\sim\end{array}$ & $\begin{array}{l}\text { 蛪 } \\
\text { N }\end{array}$ & 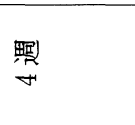 & $\begin{array}{l}\text { 絜 } \\
\text { N }\end{array}$ & $\begin{array}{l}\text { 砫 } \\
\sim\end{array}$ & 嘼 \\
\hline 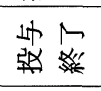 & $\frac{m}{6}$ & $\stackrel{\ominus}{ٍ}$ & $\begin{array}{l}\stackrel{2}{N} \\
\stackrel{-}{\Xi}\end{array}$ & 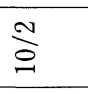 & $\frac{\sigma}{\sigma}$ & $\stackrel{\stackrel{L}{N}}{\mathrm{O}}$ & $\frac{\mathscr{N}}{\sigma}$ & $\frac{\stackrel{N}{\pi}}{\infty}$ & $\stackrel{\circ}{\sigma}$ & $\stackrel{\Delta}{\stackrel{\Delta}{=}}$ \\
\hline 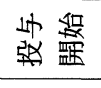 & $\frac{6}{10}$ & $\frac{\text { sิ }}{\sigma}$ & 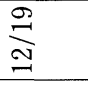 & $\frac{\bar{N}}{\sigma}$ & $\frac{10}{\sigma}$ & $\underset{O}{\Xi}$ & $\frac{\Re}{\infty}$ & $\frac{\infty}{\sigma}$ & $\frac{\hat{N}}{\infty}$ & $\frac{\widehat{N}}{\stackrel{N}{I}}$ \\
\hline $\begin{array}{l}\text { 橂 } \\
\text { 田 } \\
\text { 迕 }\end{array}$ & 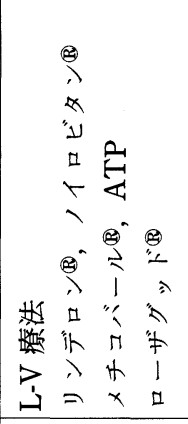 & 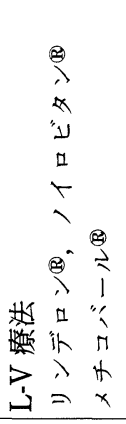 & 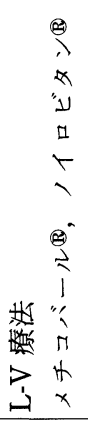 & 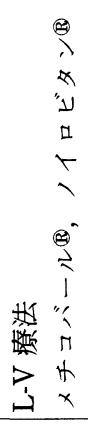 & 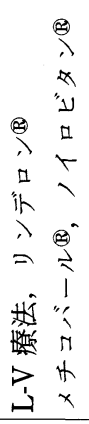 & 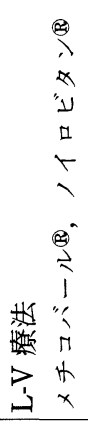 & 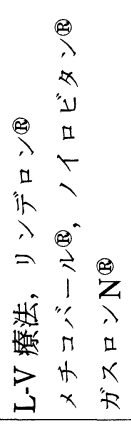 & 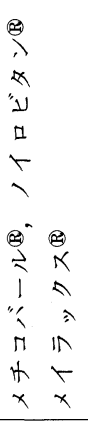 & 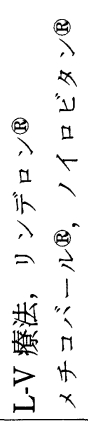 & 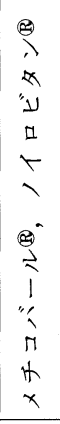 \\
\hline $\begin{array}{l}3 \\
\text { \#6 } \\
\infty\end{array}$ & 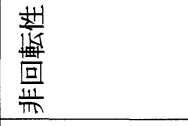 & 帮 & 祘 & 盉 & 䄸 & 欮 & 嶆 & 梷 & 颗 & 湈 \\
\hline 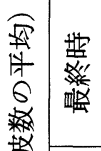 & s & $=$ & $\infty$ & $\sigma$ & $\vec{\sim}$ & $\stackrel{\infty}{N}$ & $\vec{F}$ & ల్ & $\mathscr{\infty}$ & $\infty$ \\
\hline 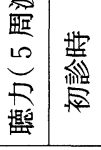 & קి & $\stackrel{R}{N}$ & $\stackrel{\bullet}{=}$ & ฉి & is & เே & 8 & ले & $\infty$ & 18 \\
\hline 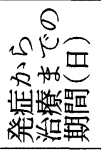 & $\stackrel{12}{\sim}$ & $\nabla$ & L & $\sim$ & $\nabla$ & 0 & $\infty$ & $\sim$ & 10 & $\infty$ \\
\hline 哂害 & HH & HH & $\mathrm{HH}$ & HH & $\mathrm{H}$ & +1 & $\mathrm{HH}$ & +7 & +1 & $+\frac{1}{4}$ \\
\hline स4 & $\tilde{6}$ & $\bar{m}$ & 12 & $\mathscr{\sim}$ & $\underset{+\infty}{\infty}$ & 8 & $\vec{m}$ & F & छै & ษ \\
\hline$\$$ & $\not x$ & $\$ x$ & 㽗 & 㧽 & 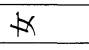 & 㧽 & 㽗 & 貯 & 㧽 & 㽗 \\
\hline 出 & & & & & & & & & & \\
\hline$\dot{\mathrm{z}}$ & $m$ & $\nabla$ & 10 & 6 & 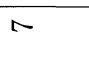 & $\infty$ & $\sigma$ & 으 & $\exists$ & $\cong$ \\
\hline
\end{tabular}




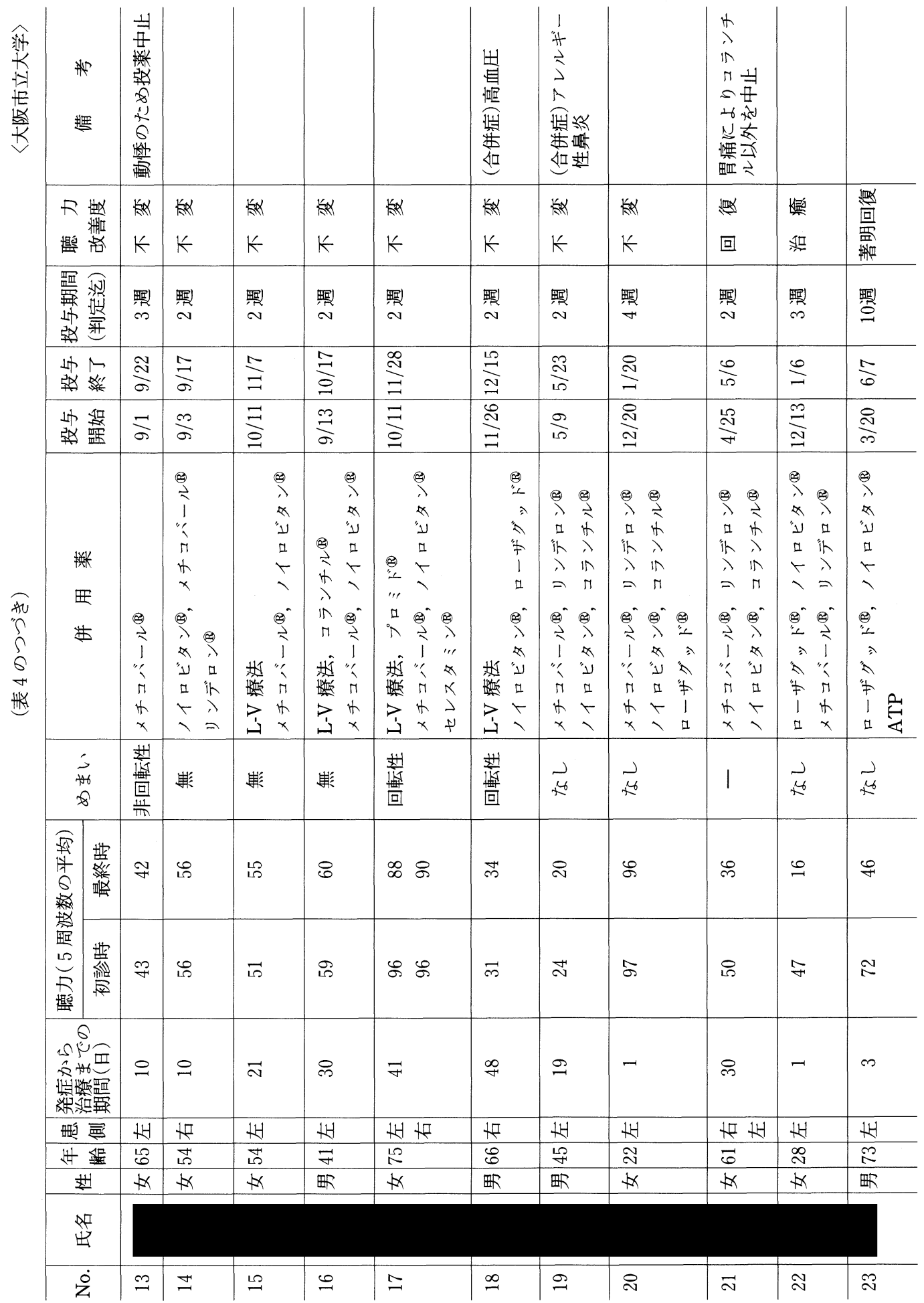




\begin{tabular}{|c|c|c|c|c|c|c|c|c|c|c|c|}
\hline 进 & & & & & & & 画 & & & & \\
\hline 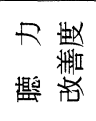 & $\begin{array}{l}\text { 四 } \\
\text { 回 }\end{array}$ & 热 & $\begin{array}{l}\text { 㥂 } \\
k\end{array}$ & $\begin{array}{l}\text { 回 } \\
\text { 迤 }\end{array}$ & 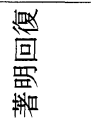 & $\begin{array}{l}\text { 回 } \\
\text { 四 }\end{array}$ & $\begin{array}{l}\text { 回 } \\
\text { 回 }\end{array}$ & $\begin{array}{l}\text { 回 } \\
\text { 回 }\end{array}$ & 颉 & 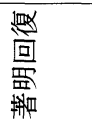 & 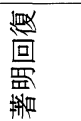 \\
\hline 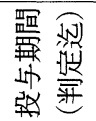 & 買 & $\begin{array}{l}\text { 睘 } \\
\text { 品 }\end{array}$ & $\begin{array}{l}\text { 鼍 } \\
\stackrel{N}{\sim}\end{array}$ & $\begin{array}{l}\text { 标 } \\
\forall \\
\forall\end{array}$ & $\begin{array}{l}\text { 䌎 } \\
\sigma\end{array}$ & $\begin{array}{l}\text { 照 } \\
+ \\
+\end{array}$ & 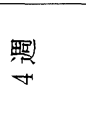 & $\begin{array}{l}\frac{\text { 枳 }}{0} \\
6\end{array}$ & $\begin{array}{l}\text { 熶 } \\
\text { + }\end{array}$ & $\begin{array}{l}\text { 貼 } \\
\infty\end{array}$ & $\begin{array}{l}\text { 睘 } \\
\text { 工 }\end{array}$ \\
\hline 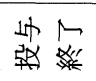 & $\stackrel{N}{\hat{N}}$ & $\stackrel{\infty}{\equiv}$ & $\stackrel{\stackrel{L}{N}}{\Xi}$ & $\stackrel{N}{N}$ & $\stackrel{\infty}{\infty}$ & $\frac{10}{\infty}$ & $\stackrel{0}{\stackrel{0}{N}}$ & $\stackrel{\sim}{\beth}$ & $\frac{10}{m}$ & $\frac{\mathfrak{N}}{m}$ & $\stackrel{\stackrel{L}{N}}{\sigma}$ \\
\hline 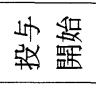 & $\stackrel{d}{\stackrel{d}{0}}$ & $\stackrel{N}{\stackrel{N}{O}}$ & $\equiv$ & $\stackrel{\infty}{\stackrel{\infty}{N}}$ & $\stackrel{0}{0}$ & $\frac{0}{N}$ & $\stackrel{\Xi}{\rightleftharpoons}$ & $\stackrel{10}{=}$ & $\stackrel{0}{i}$ & $\stackrel{\Xi}{\Xi}$ & $\stackrel{N}{0}$ \\
\hline $\begin{array}{l}\text { 椾长 } \\
\text { 进 }\end{array}$ & 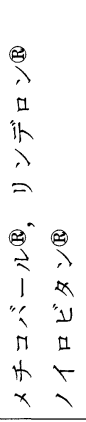 & 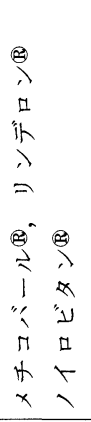 & $\overrightarrow{3}$ & 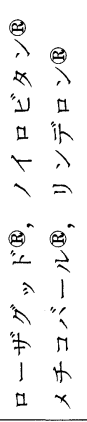 & 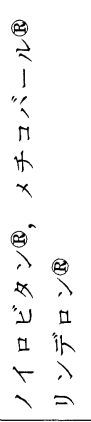 & 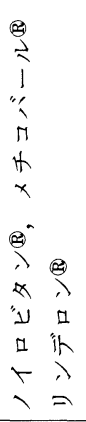 & 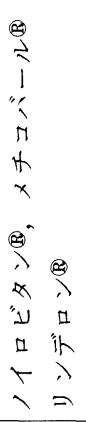 & 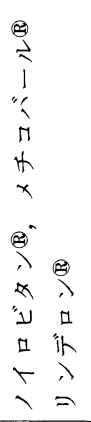 & 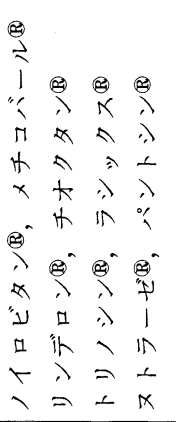 & 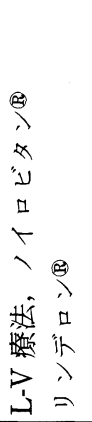 & 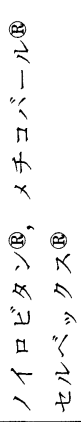 \\
\hline $\begin{array}{l}3 \\
\text { Ho } \\
8\end{array}$ & 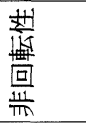 & $\overrightarrow{36}$ & $\overrightarrow{0}$ & $\overrightarrow{x^{4}}$ & $\underset{x}{x}$ & $\underset{x}{36}$ & $\overrightarrow{x^{6}}$ & $\frac{\frac{* 1}{11}}{\frac{10}{11}}$ & 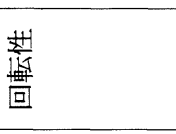 & 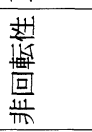 & $\overrightarrow{2}$ \\
\hline 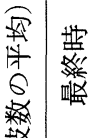 & $\ddot{8}$ & ㅇ & กิ & in & กิ & $\sigma$ & $\stackrel{L}{N}$ & 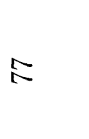 & 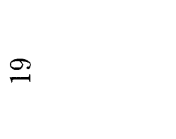 & $\begin{array}{l}\infty \\
1\end{array}$ & है \\
\hline 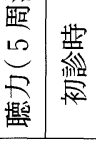 & 8 & $\infty$ & ล & 18 & ஸ́ & $\vec{m}$ & $\infty$ & ś & $\infty$ & ๙ั & $\infty$ \\
\hline 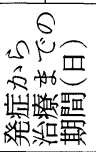 & $\Xi$ & 10 & $\nabla$ & $\sim$ & - & 으 & $\sim$ & $m$ & 10 & $N$ & م \\
\hline 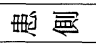 & $\mathrm{HH}$ & $\mathrm{HH}$ & + & H & HH & LI & KI & $\mathrm{HH}$ & $\mathrm{HH}$ & $H$ & $\mathrm{HH}$ \\
\hline स & ๗ & 우 & กิ & is & $\stackrel{\sim}{\sim}$ & 守 & 3 & ㅇ & $F$ & $\Xi$ & $\begin{array}{l}\infty \\
1 \\
1\end{array}$ \\
\hline$\$$ & 㧽 & $M$ & 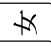 & 㽗 & $\not x$ & 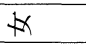 & 貯 & $X$ & $\not x$ & $\not x$ & $M$ \\
\hline 甚 & & & & & & & & & & & \\
\hline$\dot{0}$ & $\underset{\sim}{\sim}$ & 突 & $\mathscr{N}$ & ลิ & $\stackrel{\infty}{\sim}$ & 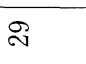 & 요 & $\vec{m}$ & ๙ & ๓ి & ले \\
\hline
\end{tabular}




\begin{tabular}{|c|c|c|c|c|c|c|c|c|c|c|c|c|}
\hline 些 & & 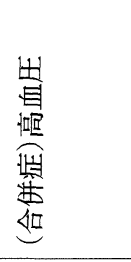 & & 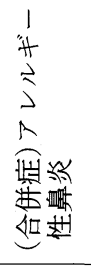 & & & & & & 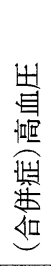 & & \\
\hline 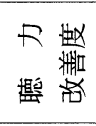 & 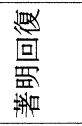 & $\begin{array}{l}\text { 紧 } \\
\text { 热 }\end{array}$ & 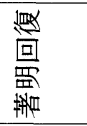 & $\begin{array}{l}\text { 回 } \\
\text { 回 }\end{array}$ & 紧 & $\begin{array}{l}\text { 焞 } \\
\text { 保 }\end{array}$ & $\begin{array}{l}\text { 回 } \\
\text { 回 }\end{array}$ & $\begin{array}{l}\text { 临 } \\
\text { 势 }\end{array}$ & $\begin{array}{l}\text { 焦 } \\
\text { 垈 }\end{array}$ & 热 & 然 & $\begin{array}{l}\text { 拨 } \\
k\end{array}$ \\
\hline 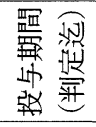 & $\begin{array}{l}\text { 䀦 } \\
\text { I }\end{array}$ & 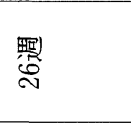 & $\begin{array}{l}\text { 㽢 } \\
\text { 吕 }\end{array}$ & $\begin{array}{l}\text { 㥸 } \\
\stackrel{2}{上}\end{array}$ & $\begin{array}{l}\text { 䀦 } \\
\sim\end{array}$ & $\begin{array}{l}\text { 略 } \\
\sim \\
\sim\end{array}$ & $\begin{array}{l}\text { 糬 } \\
\stackrel{N}{\sim}\end{array}$ & $\begin{array}{l}\text { 罟 } \\
0\end{array}$ & $\begin{array}{l}\text { 略 } \\
\text { 点 }\end{array}$ & $\begin{array}{l}\text { 枳 } \\
\infty\end{array}$ & 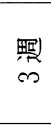 & $\begin{array}{l}\text { 䀦) } \\
\text { m }\end{array}$ \\
\hline $\begin{array}{l}\text { 出 } \\
\text { 心 }\end{array}$ & 戸 & $\frac{\pi}{\sim}$ & $\underset{\Xi}{\nexists}$ & $\stackrel{m}{10}$ & $\stackrel{\infty}{\equiv}$ & $\stackrel{ \pm}{\Xi}$ & 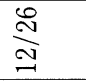 & 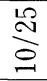 & $\frac{\nabla}{\sim}$ & $\stackrel{\oplus}{\sigma}$ & $\bar{\Xi}$ & $\frac{\nabla}{\sigma}$ \\
\hline $\begin{array}{l}\text { 边保 } \\
\text { 监 }\end{array}$ & $\stackrel{N}{\infty}$ & $\stackrel{10}{=}$ & $\stackrel{\overrightarrow{0}}{0}$ & $\stackrel{\ominus}{F}$ & $\stackrel{d}{\Delta}$ & 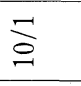 & $\stackrel{ }{\equiv}$ & $\frac{\mathscr{N}}{\infty}$ & $\frac{\Omega}{\infty}$ & $\stackrel{m}{=}$ & $\stackrel{0}{\infty}$ & $\frac{\curvearrowright}{\infty}$ \\
\hline $\begin{array}{l}\text { 椾长 } \\
\text { 开 } \\
\text { 进 }\end{array}$ & 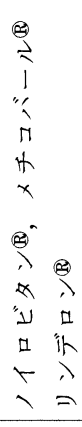 & 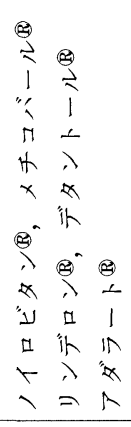 & 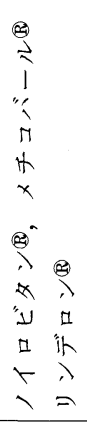 & 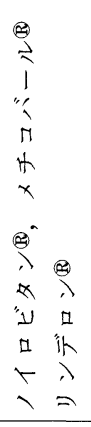 & 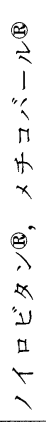 & 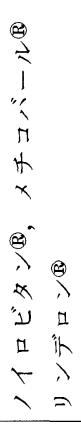 & 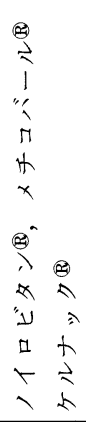 & 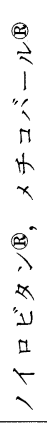 & 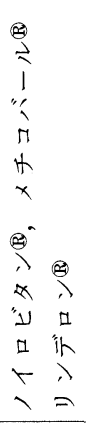 & $\overrightarrow{3}$ & 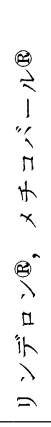 & 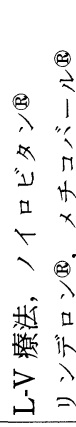 \\
\hline 3 & $\overrightarrow{6}$ & $\overrightarrow{6}$ & $\sqrt{16}$ & $\underset{x}{+6}$ & $\vec{x}$ & $\underset{6}{3}$ & 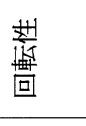 & $\vec{x}$ & $\vec{x}$ & $\overrightarrow{3}$ & $\underset{+6}{+2}$ & 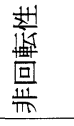 \\
\hline 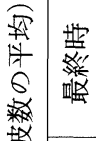 & శా & $\stackrel{10}{\longrightarrow}$ & $\stackrel{\llcorner}{\circlearrowleft}$ & $F$ & $\cong$ & $\infty$ & 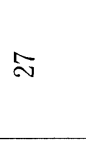 & $\approx$ & $\stackrel{10}{-1}$ & $\stackrel{m}{-1}$ & $=$ & ś \\
\hline 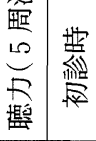 & के & $\Re$ & 8 & छூ & d & $\stackrel{N}{N}$ & F & 웜 & $\mathscr{F}$ & 0 & $\infty$ & s̀ \\
\hline 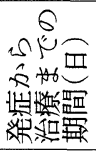 & + & $v$ & LO & $\simeq$ & 으 & $\nabla$ & 으 & $\infty$ & $\sim$ & 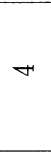 & $N$ & 음 \\
\hline 㕷焉 & 1 & 17 & H & HH & HH & + & +1 & KH & HH & $\mathrm{HH}$ & $\mathrm{HH}$ & +1 \\
\hline 过 & ஓ & 18 & $\widehat{N}$ & $\stackrel{\infty}{\rightarrow}$ & $\not$ & $\stackrel{d}{\sim}$ & $\overline{10}$ & 多 & กี & ษ & $\stackrel{\sim}{\sim}$ & $\stackrel{\infty}{10}$ \\
\hline$\#$ & $\$ x$ & $\not x$ & $M$ & 畍 & 㽗 & $\not X$ & 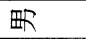 & 畍 & 㽗 & $M$ & 㽗 & 䀦 \\
\hline $\begin{array}{l}\text { 叫 } \\
\text { 出 }\end{array}$ & & & & & & & & & & & & \\
\hline$\dot{\mathrm{z}}$ & 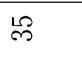 & ஜ & $\hat{n}$ & $\stackrel{\infty}{\infty}$ & लి & 우 & $\vec{F}$ & $\mathscr{\forall}$ & $\dddot{+}$ & 尹 & 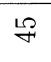 & $\mathscr{q}$ \\
\hline
\end{tabular}


(a) $1 \sim 4$ 病日

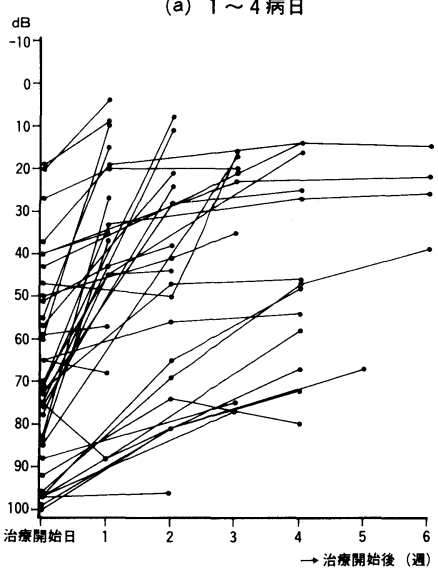

(c) $8 \sim 14$ 病日

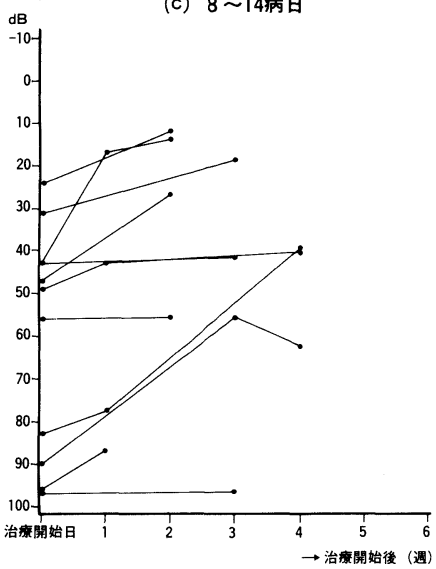

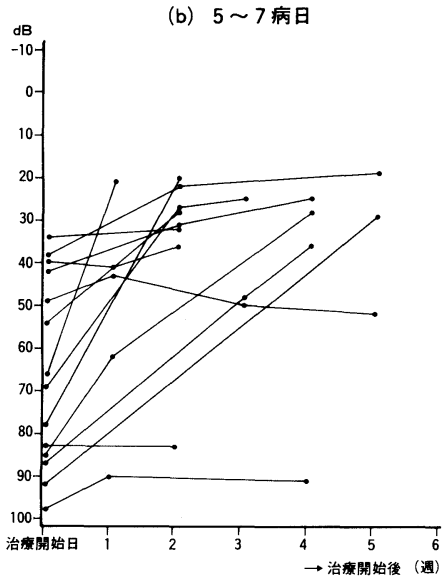

(d) 15 30病日

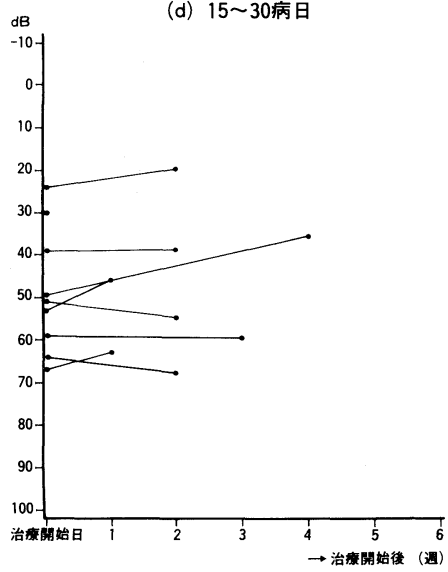

(e) 31 病日

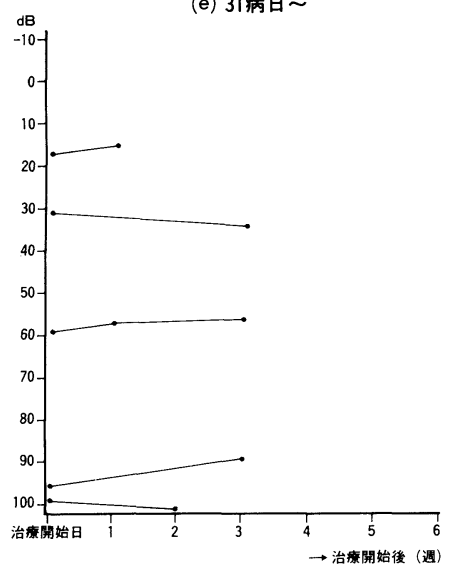

図 6 突発性難聴の発症から治療開始までの期間別にみた 各症例の聴力 ( 5 周波数平均) の推移 
表 5 発症から治療までの期間別にみた聴力の経過

\begin{tabular}{c|c|c|c|c|c}
\hline $\begin{array}{c}\text { 発症からの期間 } \\
\text { (日) }\end{array}$ & 治 癒 & 著明回復 & 回 復 & 不 変 & 計 \\
\hline $1 \sim 4$ & 10 & 13 & 6 & 5 & 34 \\
\hline $5 \sim 7$ & 2 & 5 & 3 & 5 & 15 \\
\hline $8 \sim 14$ & 1 & 2 & 2 & 5 & 10 \\
\hline $15 \sim 30$ & 0 & 1 & 1 & 7 & 9 \\
\hline $31 \sim$ & 0 & 0 & 0 & 4 & 4 \\
\hline 計 & 13 & 21 & 12 & 26 & 72
\end{tabular}

※初診時平均聴力が $30 \mathrm{~dB}$ 以内のごく軽度のものを除く.

表 6 初診時聴力レベル ( 5 周波数平均) と聴力の経過

\begin{tabular}{|c|c|c|c|c|c|}
\hline $\begin{array}{c}\text { 初診時聴力レベル } \\
(\mathrm{dB})\end{array}$ & 治癒 & 著明回復 & 回 復 & 不 変 & 計 \\
\hline $31 \sim 59$ & 7 & 1 & 7 & 9 & 24 \\
\hline $60 \sim 79$ & 7 & 6 & 3 & 1 & 17 \\
\hline $80 \sim 99$ & 1 & 10 & 4 & 5 & 20 \\
\hline $100 \sim$ & 0 & 1 & 0 & 0 & 1 \\
\hline 計 & 15 & 18 & 14 & 15 & 62 \\
\hline
\end{tabular}

※発症後14病日以内のもの.

初診時平均聴力が $30 \mathrm{~dB}$ 以内のごく軽度のものを除く.

表 7 年齢と聴力の経過

\begin{tabular}{c|c|c|c|c|c}
\hline \hline 年 秢(歳) & 治 瘉 & 著明回復 & 回 復 & 不 変 & 計 \\
\hline$\sim 39$ & 6 & 5 & 4 & 4 & 19 \\
\hline $40 \sim 59$ & 9 & 9 & 7 & 9 & 34 \\
\hline $60 \sim$ & 0 & 4 & 3 & 2 & 9 \\
\hline 計 & 15 & 18 & 14 & 15 & 62
\end{tabular}

※発症後14病日以内のもの.

初診時平均聴力が $30 \mathrm{~dB}$ 以内のごく軽度のものを除く.

表 8 耳鳴の改善度と聴力の経過

\begin{tabular}{c|c|c|c|c|c}
\hline 聴力改善度 & 治 癒 & 著明回復 & 回 復 & 不 変 & 計 \\
\hline 著度 & 8 & 3 & 1 & 1 & 13 \\
\hline 中等度改善 & 3 & 2 & 3 & 1 & 9 \\
\hline 軽 度 改 善 & 4 & 9 & 5 & 3 & 21 \\
\hline 不 変 & 1 & 0 & 0 & 9 & 10 \\
\hline 計 & 16 & 14 & 9 & 14 & 53
\end{tabular}


一方，副作用についてみると投与中止したも のが表 9 に示す如く大阪市立大学に怙ける投与 例のらち 3 例にみられた。 これら 3 例はいずれ も単独の投与ではなく他の薬剤との併用療法で あり，塩酸ビフェメランによる副作用か否かの 判定は困難である.

一方, 名古屋大学に和ける投与例では副作用 のため投与中止したものは 1 例も認められなか った。

\section{総括並びに考案}

突発性難聴の治療に打いては, その原因と病 態を考慮して行うことは当然であるが，原因は 尚不明な点が多く，しかも一元的ではないと考 えられている112)。しかしながら，図1にあげ た如く内耳循環障害，ウイルス感染が疑われ得 る場合でも，二次的には内耳循環障害を来すこ とが考えられ，内耳循環障害とそれに基づく蝸 牛の障害に対する治療が中心に行われ, 自然の 治癒過程を促進すると共に, 経過により可逆的 病変から不可逆的病変になる過程を少しでも阻 止することに主眼が扔かれている，本薬剤に拉 ける著者ら ${ }^{4)}$, 奴久妻ら ${ }^{5)}$ の動物実験成績から は蝸牛の血管・血流の改善に対して好成績が得 られており，この点からみても本薬剤は合目的 な治療薬と考兄られる。
さて，一般に薬物の有効性を検討するには， できるだけ同一の条件に招いてプラセボとの二 重盲検試験を行うことが望ましいことはいらま でもない.

しかし，本疾患の性質からみて発症後できる だけ早期に治療を開始することが望ましく，2 週間を過ぎると聴力の回復が悪くなり，約 1 力 月で聴力が固定して，それ以後は聴力回復が期 待できない疾患であることを考慮すると，人道 上二重盲検を行らことは困難である.

従って有効と思われる他の薬剤との比較検討 をすることが望まれるが，原因が不明で，しか も一元性でないと思われること，個々の症例で 予後に特に重要な因子である聴力レベルや聴力 の型が異なること，その他めまいの有無，年龄 など予後に関係のある因子が様々であること， その上に自然治瘉症例も存在すること等の理由 から厳密に同一条件下に症例別に比較すること は極めて難しい。

その上, 現在の治療法の㱀勢が, 今回の治療 も含めて単独でなく，併用療法で行われている ことも考慮に入れなければならない。

そこで，併用療法ではあるが，予後に最も強 く関与する因子である聴力低下の程度，病日を 考慮して聴力回復の推移を図 6 の様にグラフで

表 9 副作用による投与中止例

〈大阪市立大学〉

\begin{tabular}{|c|c|c|c|c|c|c|c|c|}
\hline No. & 性別 & 年路 & 内 & $\begin{array}{l}\text { 併 用 } \\
\text { 治療法 }\end{array}$ & 関連性 & 処 置 & $\beth \times ン ト$ & 安全度 \\
\hline 3 & 女 & 62 & $\begin{array}{l}\text { 顔面発疹 } \\
\text { 肝機能増悪 } \\
\text { (GOT117, GPT } \\
\text { 160, ChE0. 53, } \\
\text { TTT > } 8.0, \\
\text { ZTT>20.0) }\end{array}$ & 有 & 不明 & 中止 & $\begin{array}{l}\text { 慢性肝炎(肝硬変)について } \\
2 \text { 週に一度近医内科で経過 } \\
\text { 観察して沶りGOT, GPT } \\
30 〜 50 \text { G言われている. 肝 } \\
\text { 機能については内科主治医 } \\
\text { の承諾を得て行ったが, 顔 } \\
\text { 面発疹出現した為中止した. }\end{array}$ & 判定不能 \\
\hline 13 & 女 & 65 & 動悸 & 有 & 一 & 中止 & $\begin{array}{l}\text { 服薬後, 動悸のため投薬 } 21 \\
\text { 日で中止した. }\end{array}$ & やや問題 \\
\hline 21 & 女 & 61 & 胃痛 & 有 & 疑わしい & 中止 & $\begin{array}{l}\text { 投薬12日後朝 } 9 \text { 時胃痛と電 } \\
\text { 話あり.コランチル以外の } \\
\text { 服薬を中止した. }\end{array}$ & やや問題 \\
\hline
\end{tabular}


示した結果，好成績がみられている。オープン トライアルであり，その上併用療法であるため 他の薬剤との厳密な比較にはならないが，他の 薬剤の有効性に関する多くの文献2667) にみられ る治療成績と比べても決して劣るものではなく， むしろ良好な成績であると思われる。

勿論, 早期に治療すればする汪ど，また聴力 低下の程度が軽度のもの汪ど, 治療成績が良い こと, 60 歳以上の高年齢層では予後が悪いこと 等も他の治療法と同様である.

その上, 副作用が殆ど認められず安全性の高 い薬剤で, 外来でも安全かつ簡便に投与でき, 患者の精神的肉体的負担も少ない点を考慮すれ ば8), 発症後少しでも早い時期に治療開始を必 要とする突発性難聴の治療に第一選択として併 用療法の薬剤の一つに利用することが期待でき る.

\section{結語}

今回, 突発性難聴の治療に塩酸ビフェメラン (商品名アルナート $\left.{ }^{\circledR}\right)$ を投与し, その治療効果 を検討した。

単独治療でなく併用療法のため, 単独での治 療効果を明らかにすることは不可能であるが， 他の治療法と比べて文献的に差はみられず，乙 かも副作用が少なく, 簡単に使用できる点から みて, 少なくとも併用療法の第一選択の一薬剤 として積極的に使用してよい薬剤と考えられる.

\section{参考文献}

1）柳田則之：突発性難聴の臨床一病態, 治療, 予後に関する最近の所見一. 耳鼻臨床 $78: 299$ $\sim 311,1985$.

2）柳田則之, 丹羽英人, 中島 務, 他: 突発性難 聴の治療. 耳鼻臨床 $82: 1347 \sim 1359,1989$.

3）柳田則之, 中島 務, 設楽哲也, 他: 急性高度 難聴全国疫学調査成績. Audiology Japan 35 : 64 76, 1992.

4) Morisaki H, Nakashima $T$ and Yanagita $N$ : The effects of bifemelane hydrochloride on cochlear and cerebral blood flow. Auris Nasus Larynx 19 Suppl 1 : 67〜 73, 1992.

5）奴久妻聡一, 佐藤一, 山下公一, 他: 酸素欠 そモルモットに护けるABRに対するビフェメ ランの効果と蝸牛の変化. Ear Res Jpn 19 : $520 \sim 525,1988$.

6) 設楽哲也, 小田 恂, 立木 孝, 他 : 突発性難 聴に対する薬剂効果の評価 一Neuquinon 療法 の統計的な観察一.耳鼻 $24: 1006 \sim 1027,1978$.

7) Nakashima T, Kuno K and Yanagita N : Evaluation of prostaglandin $\mathrm{E}_{1}$ therapy for sudden deafness. Laryngoscope $99: 542 \sim 546,1989$.

8）枡谷治彦, 山根克雄, 小西一夫, 他: めまい症 例とビフェメラン (アルナート $\left.{ }^{\mathbb{B}}\right)$. 耳鼻臨床 $83:$ 487〜493, 1990.

/原稿受付 : 平成 5 年 3 月 1 日 原稿採択: 平成 5 年 3 月 5 日 別刷請求先 : 柳田則之 干466 名古屋市昭和区鶴舞町 65 名古屋大学医学部耳鼻咽喉科学教室 